\title{
What Drives Municipalities Default Risk?
}

\author{
Eymen Errais $^{1}$ \\ ${ }^{1}$ LAREQUAD and University Tunis El Manar, Tunis, Tunisia \\ Correspondence: Eymen Errais, Laboratoire de Recherche en Economie Quantitative du Développement \\ (LAREQUAD), FSEGT, University of Tunis El Manar, B.P 248, El Manar II, 2092 Tunis, Tunisia. E-mail: \\ eymen@stanfordalumni.org
}

Received: December 19, 2018

Accepted: February 3, 2019

Online Published: February 15, 2019

doi:10.5539/ijef.v11n3p49

URL: https://doi.org/10.5539/ijef.v11n3p49

\begin{abstract}
Municipal credit markets have been slow to develop in emerging markets because municipal lending risks have been difficult to identify. In this paper, we analyze the factors that impact municipalities default risks. Our data set incorporates all the 264 Tunisian Municipalities and spans a period over 7 years (2010-2016). Our methodology is based on logistic regressions ran on 40 independent variables. Our results show that factors driving good debt management could be restricted to 8 factors: Gross Savings Rate, Debt Ratio, Financial Autonomy Ratio, Level of Real Estate Tax, Budgetary Stiffness Rate, Average Debt Ratio, Average Issue Date and Average Interest Rate. The model shows strong efficiency and reliable predictive power.
\end{abstract}

Keywords: local governance, default risk, debt management, credit risk factors

\section{Introduction}

In the last few decades, municipal credit markets have been very slow to develop in emerging markets because of the difficulties to assess municipalities' risks. Financial markets found it difficult to use municipal budgets and financial reports to gauge municipalities' creditworthiness. The few market developments were only performed through central-government guarantees. However, more recently, the situation is changing with some developing countries being able to involve the private sector in municipal lending. Other countries, like Tunisia, have created financial intermediaries whose primarily job is to raise financial resources from international development institutions and lend them to local authorities.

These participants in the municipal credit market need to analyse local governance and assess credit risk. Hence, a large body of academic research has addressed the question of governments financial decentralization policy and local administrations. Through the analysis of 263 Michigan cities, (Carr \& Karuppusamy, 2010) studied the link between local government structure and per capita expenditures. (Wang et al., 2007) tested a measure of financial condition using government-wide information and found that financial condition among states varies greatly and there is a much room for improvement. (Cabaleiro et al., 2013) proposed a method for evaluating the financial health of municipalities based on three broad dimensions of sustainability, flexibility and vulnerability. (Cohen et al., 2012) built an operational model for evaluating the financial viability of local municipalities in Greece using a stochastic multi-criteria acceptability analysis combined with a disaggregation technique. (Wang \& Hou, 2012) explored the local government savings and the impact of savings on stabilizing expenditures. Examining municipal bonds, (Schwert, 2017) suggested that default risk the most important drivers of their yields at the state and local levels. Using a sample of New Jersey municipalities, (Capeci, 1994) provided an empirical study of the negative effects that a local government's fiscal decisions exert on its cost of borrowing. (Gao et al., 2018) showed evidence that state policies for distressed municipalities matter for local borrowing costs and found that in proactive states, municipal bond yield spreads increase by 3.9 percentage points.

Other studies focused on identifying factors influencing the financial condition of local governments. (Choi et al., 2010) found that population size and density to be positively associated with public spending. (Guillamon et al., 2011) found that population density, the unemployment rate and the level of immigrant population may increase local government debt. (Cabaleiro et al., 2013) examined the relationships between several variables (long term and short term debt, debt per capita, specific weight of debt by type of revenue, tax burden) and the financial health of local governments. (Holian \& Joffe, 2013) proposed a model to estimate default probabilities for bonds issued by cities and found that the most relevant independent variables are the ratio of interest and pension 
expenses to total revenue, the annual change in total revenue, the ratio of general fund surplus to general fund revenues and the ratio of general fund deficit to general fund revenues. (Cestau, 2016) examined US gubernatorial elections and found that electing a Republican governor reduces the CDS spreads and hence the default probabilities.

However, to our knowledge, there is not a large literature analysing the impact of these variables on the local governments default probabilities. One of the few papers that addressed this issue is the work carried by (Navarro-Galera et al., 2017). Based on an empirical study on 148 Spanish municipalities, their findings revealed that a lower population density, less dependent population, falling levels of per capita income and the presence of progressive local government are all risk factors for default by local governments.

In this paper, we are interested to analyze the impact of different factors on the default probabilities of Tunisian municipalities. The Tunisian context presents several specific features. First, municipalities have very few relationships with the financial system in general and the banks in particular. Municipalities are essentially funded by la Caisse des Prêts et de Soutien des Collectivités Locales (CPSCL). CPSCL is a government organisation that manages the allocation of government funds and development finance institutions (DFIs) resources toward municipalities and local communities. CPSCL was first created in 1902 by the French administration under the name of "Caisse des Prêts Communaux Tunisiens". Its status has since evolved toward more financial and management autonomy and it is under the current name and status (EPNA: Non Administrative State Owned Company) since 1975.

After the revolution of 2011, the Tunisian parliament has voted a new constitution in 2014 pushing for the virtue of decentralization. This is was achieved through the vote of a new local communities code and the organisation of the first municipal elections in May 2018. Many seasoned observers are worried that the the new municipalities do not have the financial means of their ambitions. The transition from centralized to devolved power could be proved to be very bumpy. The disparities between provinces, which include very different levels of unemployment, access to social services and infrastructure, fuelled the revolt of 2011 and could provoke further trouble in the future if they are not addressed. The great unknown today is whether the new municipal code will deliver faster and more socially inclusive growth across the country where regional disparities have grown alarmingly over the past decades?

To better understand the future, you must understand the past. It is therefore worth considering the causes of local economic failures in recent years in general and the factors that impact local communities default risks in particular. This paper tries to address this issue.

The reminder of the paper is organised as follows. In section II, we discuss the research methodology and model set up. Section III analyses the data used. Section IV displays the results and section V concludes.

\section{Methodology and Model Set Up}

Let $(\Omega, F, \mathbb{F}, Q)$ be a filtred proability space endowed with the filtration $\mathbb{F}=\left\{\mathrm{F}_{t}: t \geq 0\right\}, \mathrm{F}_{t} \subset \mathrm{F}$, associated with Markov processes with left-limit right-continuous trajectories $\left\{X_{i t}, t \geq 0, i \in I\right\}$ where $I$ is a set index. The filtration $\mathrm{F}$, hence, represents the information flow provided from different variables $X$. In our context, the process $X$ is defined by 40 variables spanning from financial variables to behaviour variables.

We define the process $Y=\left\{Y_{t}: t \geq 0\right\}$ as a default process. Default is measured by a delay of more than certain days in debt payment ( 90 days in our context). Default is a binary process that could be written as follows:

$$
Y_{t}=\left\{\begin{array}{l}
1 \text { if Default at time } \mathrm{t} \\
0 \text { if Survival at time } \mathrm{t}
\end{array}\right.
$$

We are interested in computing the conditional expectation of Default :

$$
E\left[Y_{t} \mid \mathrm{F}_{t}\right]=P\left[Y_{t}=1|| \mathrm{F}_{t}\right]
$$

One might think of running an Ordinary Least Square (OLS) of the above probability on a set of dependant variable:

$$
E\left[Y_{t} \mid \mathrm{F}_{t}\right\rfloor=P\left[Y_{t}=1|| \mathrm{F}_{t}\right]=\beta_{0}+\beta_{1} X_{1 t}+\beta_{2} X_{2 t}+\cdots+\beta_{n} X_{n t}
$$

Unfortunately several issues will be faced when performing an OLS mainly:

- The linear combination of the dependant variables is a real term and not a probability

- In the sample set, we see Y and not the Default probability. 
- The OLS hypothesis, mainly homoscedasticity and normality of error terms, could not prevail and hence will impact any inferential statistics (coefficient estimation, etc.)

Therefore, we will use the Logit of $P\left[Y_{t}=1|| \mathrm{F}_{t}\right]$ as follows :

$$
\ln \left[\frac{\Pi(X)}{1-\Pi(X)}\right]=\beta_{0}+\beta_{1} X_{1 t}+\beta_{2} X_{2 t}+\cdots+\beta_{n} X_{n t}
$$

where $\Pi_{t}(x)=\frac{\exp \left(\beta_{0}+\beta_{1} X_{1 t}+\beta_{2} X_{2 t}+\cdots+\beta_{n} X_{n t}\right)}{1+\exp \left(\beta_{0}+\beta_{1} X_{1 t}+\beta_{2} X_{2 t}+\cdots+\beta_{n} X_{n t}\right)} \quad$ being the cumulative function of the logistic law. Note that $1-\Pi_{t}(x)=P\left[Y_{t}=0|| \mathrm{F}_{t}\right]$

Hence by performing the logistic regression we are able to estimate the coefficients $\left\{\beta_{0}, \beta_{1}, \beta_{2}, \ldots, \beta_{n}\right\}$ to come up with the final result:

$$
P\left[Y_{t}=1|| \mathrm{F}_{t}\right]=\frac{1}{1+\exp \left(-\beta_{0}-\beta_{1} X_{1 t}-\beta_{2} X_{2 t}-\cdots-\beta_{n} X_{n t}\right)}
$$

The methodology we propose in this paper is to start with a large set of variables (in our case 40 variables) to come up with the significant variables predicting default by through data analysis and logistic regression.

In a nutshell, the steps that we undertake in this paper could be summarized as follows:

1) Check the quality of data for every variable and only keep variables with reliable data.

2) Perform individual statistical analysis to better grasp the behaviour of each variable (mean, standard deviation, quantiles, etc.).

3) Compute the correlation of each variable with default. We use Spearman rho for continuous variable and Cramer's V for discrete variables. We eliminate the variables that have very low correlation with default

4) Perform multicollinearity test for the remaining variables to eliminate the variables that provide the same information. This step allows the model to have more consistent parameters as multicollinearity can cause estimation inefficiency.

5) Run logistic regression and do significance test for every estimated parameter

6) Keep only the statistically significant variables

7) Repeat steps 5 and 6 until getting statistically significant variables

\section{Data}

The data sample used in this paper is composed of 264 municipalities spanning over 7 year period, from 2010 to 2016, making a total of 1848 data points. For every data point we have an observations set of 40 variables divided over three categories as displayed in Table 1 and described in Table 2. Default is measured by a delay of more than 90 days in debt payment. Table 3 presents some descriptive statistics for each variable.

Table 1. Division of variables by category

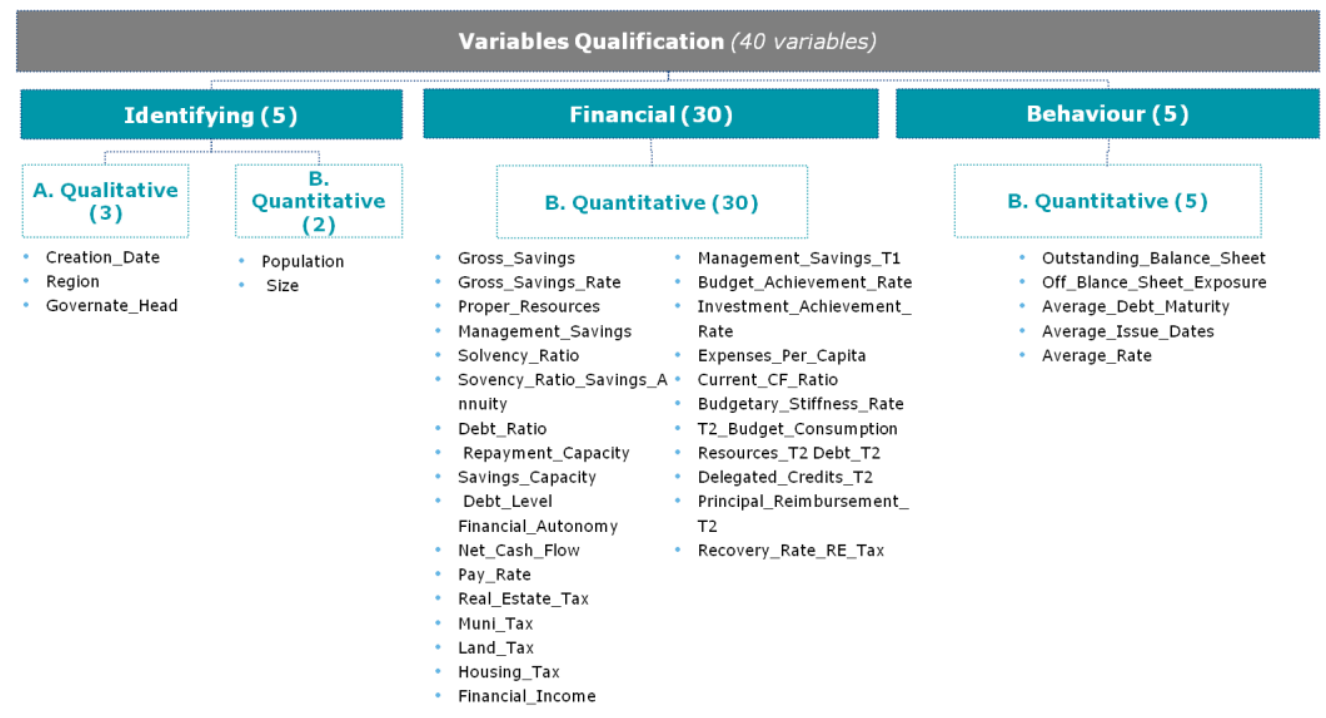


Table 2. Variable description

\begin{tabular}{|c|c|}
\hline Variables & Description \\
\hline \multicolumn{2}{|l|}{ Identifying Variables } \\
\hline Creation_Date & Date of creation of the municipality \\
\hline Region & The region the municipality is from \\
\hline Governate_Head & Whether the municipality is head of the governate or not \\
\hline Population & The municipality population size \\
\hline Size & The municipality size \\
\hline \multicolumn{2}{|l|}{ Behaviour Variables } \\
\hline Outstanding_Balance_Sheet & The amount owed by the municipality \\
\hline Off_Blance_Sheet_Exposure & Debt that is not on the municipality balance sheet \\
\hline Average_Debt_Maturity & The average time of municipalities time to maturity debt \\
\hline Average_Issue_Dates & Average debt issue dates \\
\hline Average_Rate & Weighted average interest rate applied to the municipality \\
\hline \multicolumn{2}{|l|}{ Financial Variables } \\
\hline Gross_Savings & The gross savings made my each municipalities per period \\
\hline Gross_Savings_Rate & Gross_Savings / Total Resources \\
\hline Proper_Resources & The municipalities own resources ( by substucting governement donations) \\
\hline Management_Savings & Gross Savings + interests \\
\hline Solvency_Ratio & Outstanding Debt / Gross Savings \\
\hline Sovency_Ratio_Savings_Annuity & Gross_Savings / Annuity \\
\hline Debt_Ratio & Outstanding Debt / Total Resources \\
\hline Repayment_Capacity & Gross Savings / Annuity \\
\hline Savings_Capacity & Gross Savings / Total Resources \\
\hline Debt_Level & Annuity / Total Resources \\
\hline Financial_Autonomy & Proper_Resources / Total Resources \\
\hline Net_Cash_Flow & Gross_Savings - Debt Reimbursement \\
\hline Pay_Rate & Municipality payable Resources / Governement Resources \\
\hline Real_Estate_Tax & Real Estate Tax / Proper_Resources \\
\hline Muni_Tax & Municipal Tax /Proper_Resources \\
\hline Land_Tax & Taxes from non built lands / Proper_Resources \\
\hline Housing_Tax & Housing Tax \\
\hline Financial_Income & Financial income from investments / Proper_Resources \\
\hline Management_Savings_T1 & Management_Savings / Income from T1 \\
\hline Budget_Achievement_Rate & Budget disbursed / Total Budget \\
\hline Investment_Achievement_Rate & Investment disbursed / Total Investment budgetised \\
\hline Expenses_Per_Capita & Total operational expenses / Number of habitants \\
\hline Current_CF_Ratio & Net Cash Flow / Total Resources \\
\hline Budgetary_Stiffness_Rate & (Annuity + Municipality payable Resources) / Total Resources \\
\hline T2_Budget_Consumption & $\mathrm{T} 2$ disbursed / Total $\mathrm{T} 2$ \\
\hline Resources_T2 & Resources coming from $\mathrm{T} 2$ / Income from $\mathrm{T} 2$ \\
\hline Debt_T2 & Total Debt / Income from T2 \\
\hline Delegated_Credits_T2 & Delegated Credits / Income from T2 \\
\hline Principal_Reimbursement_T2 & Principal Reimbursement / Income from T2 \\
\hline Recovery_Rate_RE_Tax & Recovery rate ratio of Real_Estate_Tax \\
\hline
\end{tabular}


Table 3. Variables statistics

\begin{tabular}{|c|c|c|c|c|c|c|c|}
\hline Statistique & Min & Max & 1st Quartile & Median & 3rd Quartile & Average & Std dev \\
\hline Gross_Savings & 233930 & 532321133 & 95424 & 215749 & 539408 & 855582 & 12426580 \\
\hline Gross_Savings_Rate & $-50,75 \%$ & $100,00 \%$ & $11,90 \%$ & $20,46 \%$ & $29,24 \%$ & $21,50 \%$ & $13,54 \%$ \\
\hline Proper_Resources & - & 532480623 & 335843 & 642800 & 1688924 & 2096961 & 13383068 \\
\hline Management_Savings & 132192 & 532334883 & 120071 & 255924 & 647527 & 956443 & 12447396 \\
\hline Solvency_Ratio & 338,85 & 920332,83 & 1,46 & 2,79 & 5,29 & 657,92 & 21840,74 \\
\hline Sovency_Ratio_Savings_Annuity & 3 & 5019 & 1 & 2 & 3 & 5 & 117 \\
\hline Debt_Ratio & $0,00 \%$ & $363,58 \%$ & $38,00 \%$ & $58,85 \%$ & $82,82 \%$ & $62,07 \%$ & $35,98 \%$ \\
\hline Repayment_Capacity & 2,88 & 6867,67 & 0,81 & 1,51 & 2,61 & 5,75 & 159,72 \\
\hline Savings_Capacity & $-50,75 \%$ & $100,00 \%$ & $11,90 \%$ & $20,46 \%$ & $29,24 \%$ & $21,50 \%$ & $13,54 \%$ \\
\hline Debt_Level & $0,00 \%$ & $48,76 \%$ & $9,52 \%$ & $12,82 \%$ & $16,88 \%$ & $13,56 \%$ & $6,00 \%$ \\
\hline Financial_Autonomy & $0,00 \%$ & $100,00 \%$ & $53,67 \%$ & $64,43 \%$ & $73,42 \%$ & $62,23 \%$ & $15,08 \%$ \\
\hline Net_Cash_Flow & 6506862 & 532321133 & 44533 & 131943 & 346634 & 654893 & 12402766 \\
\hline Pay_Rate & $0,00 \%$ & $942,55 \%$ & $52,75 \%$ & $59,07 \%$ & $66,51 \%$ & $60,18 \%$ & $26,41 \%$ \\
\hline Muni_Tax & $0,00 \%$ & $1516,47 \%$ & $10,39 \%$ & $20,17 \%$ & $32,51 \%$ & $23,66 \%$ & $38,12 \%$ \\
\hline Housing_Tax & $0,00 \%$ & $65,09 \%$ & $0,00 \%$ & $0,00 \%$ & $0,05 \%$ & $1,47 \%$ & $5,97 \%$ \\
\hline Financial_Income & $0,00 \%$ & $4709,82 \%$ & $1,75 \%$ & $8,27 \%$ & $21,25 \%$ & $17,06 \%$ & $110,48 \%$ \\
\hline Real_Estate_Tax & $0,00 \%$ & $35,48 \%$ & $2,99 \%$ & $5,69 \%$ & $9,14 \%$ & $6,81 \%$ & $5,16 \%$ \\
\hline Land_Tax & $0,00 \%$ & $44,17 \%$ & $0,46 \%$ & $1,30 \%$ & $3,09 \%$ & $2,52 \%$ & $3,63 \%$ \\
\hline Management_Savings_T1 & $-50,75 \%$ & $227,20 \%$ & $15,48 \%$ & $25,22 \%$ & $33,76 \%$ & $25,41 \%$ & $14,92 \%$ \\
\hline Budget_Achievement_Rate & $0,00 \%$ & $118910,17 \%$ & $94,48 \%$ & $103,80 \%$ & $115,79 \%$ & $171,58 \%$ & $2763,85 \%$ \\
\hline Investment_Achievement_Rate & $0,00 \%$ & $91904,54 \%$ & $0,00 \%$ & $26,86 \%$ & $89,68 \%$ & $326,90 \%$ & $3160,41 \%$ \\
\hline Expenses_Per_Capita & - & 536 & 46 & 65 & 87 & 71 & 50 \\
\hline Current_CF_Ratio & $0,00 \%$ & $205,59 \%$ & $78,03 \%$ & $87,14 \%$ & $94,59 \%$ & $85,14 \%$ & $14,32 \%$ \\
\hline Budgetary_Stiffness_Rate & $0,00 \%$ & $194,89 \%$ & $50,48 \%$ & $59,69 \%$ & $70,29 \%$ & $60,76 \%$ & $16,80 \%$ \\
\hline T2_Budget_Consumption & $0,00 \%$ & $6668,88 \%$ & $44,63 \%$ & $67,41 \%$ & $95,54 \%$ & $79,19 \%$ & $166,10 \%$ \\
\hline Resources_T2 & $0,00 \%$ & $591,20 \%$ & $53,25 \%$ & $76,46 \%$ & $92,83 \%$ & $69,45 \%$ & $32,72 \%$ \\
\hline Debt_T2 & $0,00 \%$ & $100,00 \%$ & $0,00 \%$ & $6,02 \%$ & $18,20 \%$ & $11,18 \%$ & $14,10 \%$ \\
\hline Delegated_Credits_T2 & $0,00 \%$ & $97,59 \%$ & $0,00 \%$ & $0,03 \%$ & $8,83 \%$ & $7,99 \%$ & $15,22 \%$ \\
\hline Principal_Reimbursement_T2 & $0,00 \%$ & $6437,22 \%$ & $5,38 \%$ & $11,47 \%$ & $22,41 \%$ & $22,31 \%$ & $152,07 \%$ \\
\hline Recovery_Rate_RE_Tax & $0,00 \%$ & $512,70 \%$ & $2,00 \%$ & $9,10 \%$ & $17,50 \%$ & $13,61 \%$ & $22,46 \%$ \\
\hline Creation_Date & 01-janv-57 & 13-sept-04 & & & & $10-$ oct-62 & 04-août-09 \\
\hline Region & 1,0 & 8,0 & 2,0 & 3,0 & 6,0 & 3,8 & 2,4 \\
\hline Population & 784 & 652432 & 6341 & 11772 & 30000 & 27709 & 52409 \\
\hline Size & 13 & 4966300 & 400 & 1045 & 2500 & 6810 & 120646 \\
\hline Governate_Head & - & 1,00 & - & - & - & 0,09 & 0,28 \\
\hline Outstanding_Balance_Sheet & - & 43486517 & 296863 & 611916 & 1349704 & 1238734 & 2572165 \\
\hline Off_Blance_Sheet_Exposure & - & 3138665 & - & - & 50293 & 73202 & 210487 \\
\hline Average_Debt_Maturity & 10,17 & 20,00 & 13,04 & 13,61 & 14,09 & 13,56 & 0,92 \\
\hline Average_Issue_Dates & 05-mai-87 & 17-juil-12 & 13-août-03 & 28-mai-05 & 19-févr-07 & 12-mai-05 & 03-sept-02 \\
\hline Average_Rate & 2,00 & 8,11 & 5,62 & 6,82 & 7,13 & 6,24 & 1,27 \\
\hline
\end{tabular}

\section{Results}

The first analysis of our data shows that in $57.9 \%$ a loan default occured and in $42.1 \%$ of the cases there was no default. The three statistics (LR, Score and Wald) reject the null hypothesis $(\mathrm{H} 0=57.9 \%)$, i.e. the model is statistically different from just a random sampling of default, as it can be seen in Table 4.

Table 4. Test of the null Hypothesis H0 : Y = 57.9\%

\begin{tabular}{cccc}
\hline Statistics & DDL & $\mathbf{K h i}^{\mathbf{2}}$ & $\mathbf{P r}>\mathbf{K h \mathbf { h } ^ { \mathbf { 2 } }}$ \\
\hline$-2 \log ($ Vraisemblance $)$ & 8 & 848,230 & $<0,0001$ \\
Score & 8 & 619,852 & $<0,0001$ \\
Wald & 8 & 382,203 & $<0,0001$ \\
\hline
\end{tabular}

Table 5 presents the estimated coefficients of the logistic regression as well as their statistical significance and other statistics of the final model. We reached the final model after 11 iterations with the final model having 8 significant variables. The model is statistically significant and according to the coefficients, four variables have positive effect on default risk and four have negative effects. 
Table 5. Coefficients and statistics of the variables included in the final model

\begin{tabular}{ccccccc}
\hline Source & Coef & Std Dev & Wald Khi $^{2}$ & Wald Lower (95\%) & Wald Upper (95\%) & Pr > LR \\
\hline Gross_Savings_Rate & $-2,982$ & 0,660 & 20,428 & $<0,0001$ & $-4,275$ & $-1,689$ \\
Debt_Ratio & 0,837 & 0,212 & 15,655 & $<0,0001$ & 0,422 & 1,252 \\
Financial_Autonomy & $-3,059$ & 0,514 & 35,353 & $<0,0001$ & $-4,067$ & $-2,050$ \\
Real_Estate_Tax & $-13,662$ & 1,466 & 86,821 & $<0,0001$ & $-16,535$ & $-10,788$ \\
Budgetary_Stiffness_Rate & 4,640 & 0,606 & 58,678 & $<0,0001$ & 3,453 & 5,828 \\
Average_Debt_Maturity & 0,307 & 0,069 & 20,097 & $<0,0001$ & 0,173 & 0,442 \\
Average_Issue_Dates & $1,358 \mathrm{E}-04$ & $2,852 \mathrm{E}-05$ & 22,674 & $<0,0001$ & $7,991 \mathrm{E}-05$ & $1,917 \mathrm{E}-04$ \\
Average_Rate & $-1,345$ & 0,108 & 155,215 & $<0,0001$ & $-1,556$ & $-1,133$ \\
\hline
\end{tabular}

The results show that Gross_Savings_Rate (Gross savings/Total Resources) significant with a negative sign. This is expected as the higher is the gross saving rate the lower is the default probability. When put into the logistic function, a negative coefficient will decrease the default probability while a positive coefficient will increase it. Hence, Gross_Savings_Rate, Financial_Autonomy (ProperResources/Total Resources) and the Real_Estate_Tax have negative signs as expected since a better financial autonomy and more income from real estate taxes can only decrease the default probabilities. However the negative sign of the Average_Rate is more difficult to explain as we could have expected that the higher the average rate, the riskier the municipality and the higher the default probability. Our best explanation of this results lies in the fact that the rates were administrated by CPSCL in the past years not based on the risk rating of the counterparty but on the purpose of the loan. To push our analysis further, we interviewed financial analysts at CPSCL to better understand how interest rates loans were fixed. The results of our interviews are displayed in Table 6 .

Table 6. Interest rate and maturity by project nature

\begin{tabular}{ccc}
\hline Project Nature & Interest Rate & Maturity \\
\hline Infrastructure & $7 \%$ & 15 \\
Development & $7 \%$ & 15 \\
Administrative buildings & $7 \%$ & 15 \\
Maintenance & $7 \%$ & 15 \\
Projects with economic purpose & $8 \%$ & 10 \\
Equipment acquisition & $6 \%$ & 7 \\
Studies & $7 \%$ & 5 \\
\hline
\end{tabular}

Table 6 confirms our thoughts and it is clear that interest rates are determined with respect of the loan purpose and not counterparty risk. As it can be seen in Table 6, projects with economic purpose get the highest rate, however these projects have more chances to generate revenues and hence be able to pay back their debt, which explains the negative sign.

Due to the level effect of each variables, the coefficients values can be misleading as one might think, for example, that Real_Estate_Tax is the most important factor. Therefore, we display in Table 7 and Figure 1 the normalized coefficients.

Table 7. Normalized coefficients

\begin{tabular}{ccccccc}
\hline Source & Coef & Std Dev & Wald Khi ${ }^{2}$ & Wald Lower $(\mathbf{9 5} \%)$ & Wald Upper $(\mathbf{9 5 \%})$ & Pr $>$ LR \\
\hline Gross_Savings_Rate & $-0,223$ & 0,049 & 20,428 & $-0,319$ & $-0,126$ & $<0,0001$ \\
Debt_Ratio & 0,166 & 0,042 & 15,655 & 0,084 & 0,248 & $<0,0001$ \\
Financial_Autonomy & $-0,254$ & 0,043 & 35,353 & $-0,338$ & $-0,170$ & $<0,0001$ \\
Real_Estate_Tax & $-0,389$ & 0,042 & 86,821 & $-0,470$ & $-0,307$ & $<0,0001$ \\
Budgetary_Stiffness_Rate & 0,430 & 0,056 & 58,678 & 0,320 & 0,540 & $<0,0001$ \\
Average_Debt_Maturity & 0,273 & 0,061 & 20,097 & 0,154 & 0,393 & $<0,0001$ \\
Average_Issue_Dates & 0,292 & 0,061 & 22,674 & 0,172 & 0,413 & $<0,0001$ \\
Average_Rate & $-1,112$ & 0,089 & 155,215 & $-1,287$ & $-0,937$ & $<0,0001$ \\
\hline
\end{tabular}




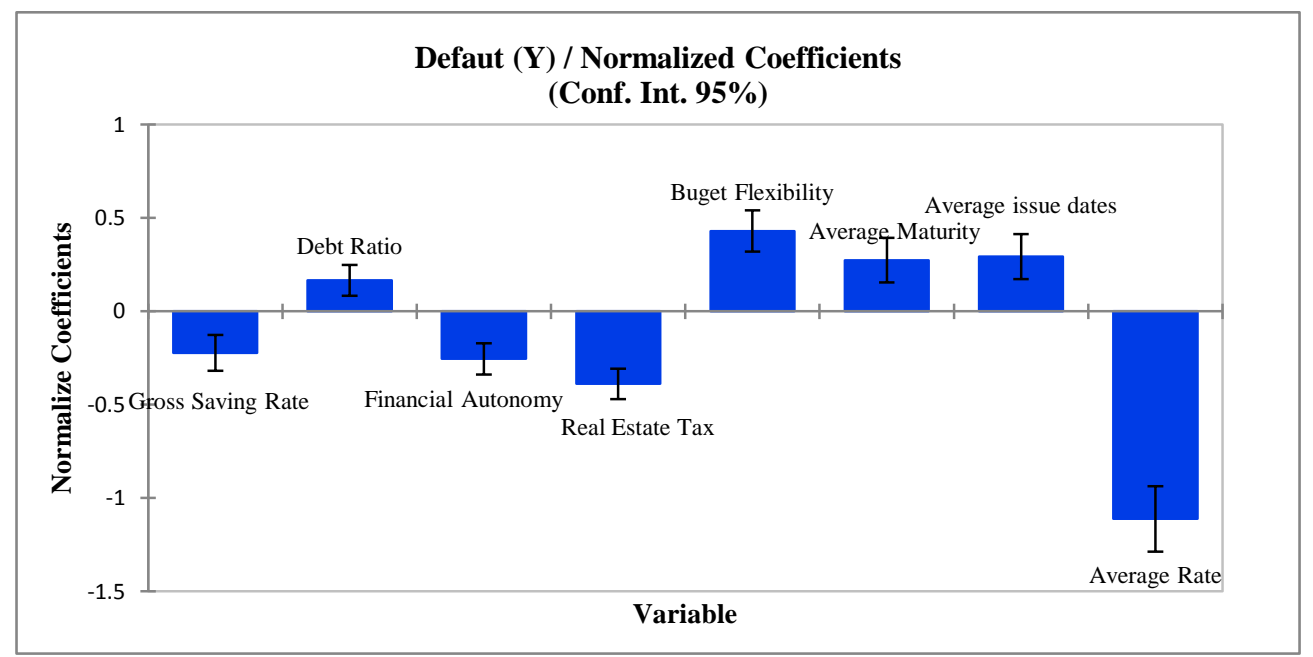

Figure 1. Normalized coefficients

The correlation matrix in Table 8 shows that the correlations between the dependent variables are very small, which confirms that there is no relationship among these variables that would account for the event studied.

Table 8. Correlation matrix between dependent variables

\begin{tabular}{cccccccc}
\hline Variables & & & & & & & \\
\hline Gross_Savings_Rate & $\mathbf{1 , 0 0 0}$ & & & & & & \\
Debt_Ratio & $-0,103$ & $\mathbf{1 , 0 0 0}$ & & & & & \\
Financial_Autonomy & 0,291 & 0,157 & $\mathbf{1 , 0 0 0}$ & & & & \\
Real_Estate_Tax & $-0,114$ & 0,084 & $-0,339$ & $\mathbf{1 , 0 0 0}$ & & & \\
Budgetary_Stiffness_Rate & $-0,661$ & 0,286 & $-0,239$ & $-0,032$ & $\mathbf{1 , 0 0 0}$ & & $\mathbf{1 , 0 0 0}$ \\
Average_Debt_Maturity & $-0,005$ & 0,175 & 0,135 & $-0,026$ & 0,008 & $\mathbf{1 , 0 0 0}$ & \\
Average_Issue_Dates & 0,030 & 0,136 & 0,076 & $-0,055$ & 0,008 & 0,749 & $\mathbf{1 , 0 0}$ \\
Average_Rate & 0,146 & 0,273 & 0,205 & 0,027 & $-0,160$ & 0,574 & 0,482 \\
\hline
\end{tabular}

As a measure of performance of the model, the Receiver Operating Characteristic (ROC) curve of the model approaches the upper-left corner of the graph with the Area Under Curve (AUC) coefficient close to 1, which confirms that the model discriminates sufficiently well between groups of municipalities.

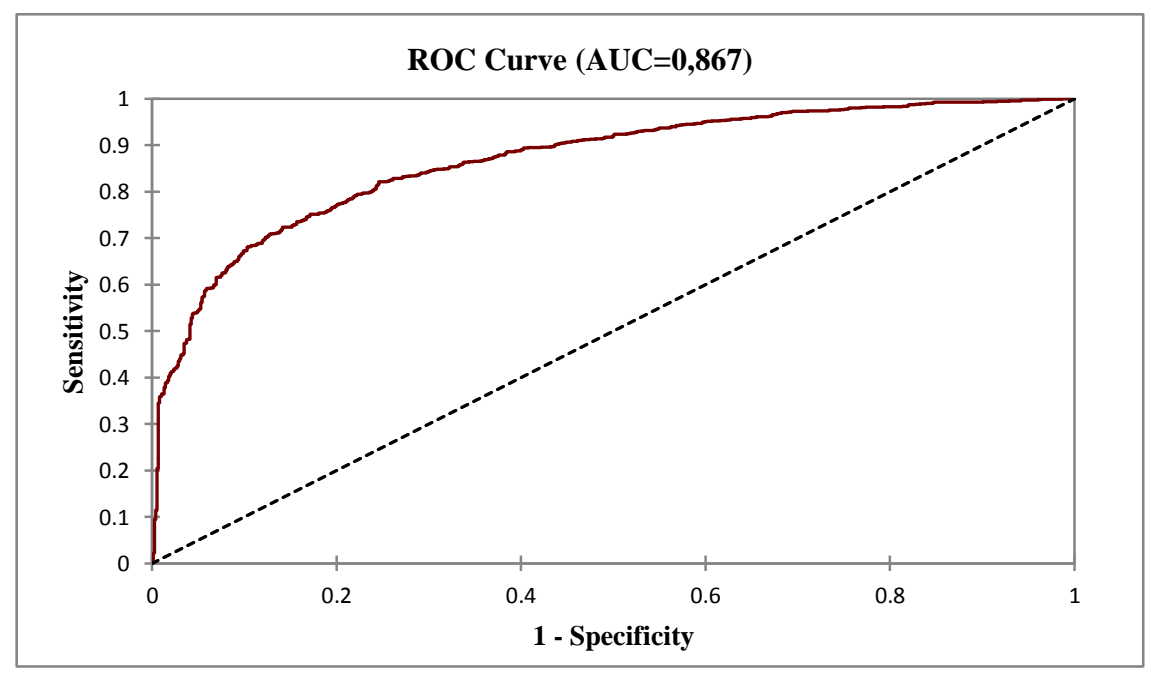

Figure 2. The final model ROC curve 
Table 9 displays the classification matrix, i.e. the table of estimated versus observed values. It shows the accuracy of the obtained classification. It can be seen that an accuracy of $78.84 \%$ is obtained in the correct classification of the database items. The default is predicted with any accuracy of $81.21 \%$ (Sensitivity), while survival probability is predicted with an accuracy of $75.58 \%$ (Specificity).

Table 9. Classification matrix

\begin{tabular}{ccccc}
\hline From $\backslash$ To & Non-default & Default & Total & $\%$ correct \\
\hline Non-default & 588 & 190 & 778 & $75,58 \%$ \\
Default & 201 & 869 & 1070 & $81,21 \%$ \\
Total & 789 & 1059 & 1848 & $78,84 \%$ \\
\hline
\end{tabular}

\section{Conclusion}

Following the revolution of 2011, the Tunisian parliament has voted a new constitution in 2014 putting the importance of decentralization forward. This is was achieved through the vote of a new local communities code and the organisation of the first municipal elections in May 2018. The first questions that were raised after the local elections: do municipalities have the financial means and power to perform their duties properly? Do they have the capabilities to manage their financial resources properly? What is behind some of the municipalities financial troubles?

In this paper, we focused on analysing the factors impacting Municipalities defaults in the Tunisian context. We showed that there are mainly eight factors explaining default: Gross Savings Rate, Debt Ratio, Financial Autonomy Ratio, Level of Real Estate Tax, Budgetary Stiffness Rate, Average Debt Ratio, Average Issue Date and Average Interest Rate . Our model showed strong efficiency and reliable predictive power.

The findings of the present article may provide useful information for the rulers as it will allow them to better allocate resources cross Municipalities. More specifically, by being able to compute the default probabilities (DP), the governors can compute the Expected Losses per municipality and hence know how much capital each municipality could consume (in the meaning of Basel III). This is done through the modeling of Loss Given Defaults (LGD) and Exposure at Default (EAD) by municipality as Expected Loss is the multiplication of DP by LGD and EAD. Once the Expected Loss computed, governors can better allocate resources cross local governments and hence improve its decentralization policy. The modeling of LGD and EAD in the local governance context will be performed in future research.

\section{References}

Cabaleiro, R., Buch, E., \& Vaamonde, A. (2013). Developing a Method to Assessing the Municipal Financial Health. The American Review of Public Administration, 43(6), 729-751. https://doi.org/10.1177/0275074012451523

Capeci, J. (1994). Local Fiscal Policies, Default Risk and Municipal Borrowing Costs. Journal of Public Economics, 53(1), 73-89. https://doi.org/10.1016/0047-2727(94)90014-0

Carr, J. B., \& Karuppusamy, S. (2010). Reassessing the Link between City Structure and Fiscal Policy. The American Review of Public Administration, 40(2), 209-228. https://doi.org/10.1177/0275074009334641

Cestau, D. (2016). Do Bondholders Prefer Republican or Democratic Governors? Working paper. http://dx.doi.org/10.2139/ssrn.2807928

Choi, J. H., Kim, C., Kim, J. B., \& Zang, Y. (2010). Audit Office Size, Audit Quality and Audit Pricing. Auditing: A Journal of Practice and Theory, 29(1), 73-97. https://doi.org/10.2308/aud.2010.29.1.73

Cohen, S., Doumpos, M., Neofytou, E., \& Zopoundis, C. (2012). Assessing Financial Distress where Bankruptcy is not an Option: An alternative Approach for Local Municipalities. European Journal of Operational Research, 218(1), 270-279. https://doi.org/10.1016/j.ejor.2011.10.021

Gao, P., Lee, C., \& Murphy, D. (2018). Municipal Borrowing Costs and State Policies for distressed Municipalities. Journal of Financial Economics. https://doi.org/10.1016/j.jfineco.2018.10.009.

Guillamon, M., Benito, B., \& Bastida, F. (2011). Evaluation of local government debt in Spain. Revista Espanola de Financiacion y Contabilidad, 40(150), 251-285.

Holian, M., \& Joffe, M. (2013). Assessing Municipal Bond Default Probabilities. Working paper. https://doi.org/10.2139/ssrn.2258801 
Navarro-Galera, A., Lara-Rubio, J., Buendia-Carrillo, D., \& Rayo-Canton, S. (2017). What can increase the Default Risk in Local Governments? International Review of Administrative Sciences, 83(2), $397-419$. https://doi.org/10.1177/0020852315586308

Schwert, M. (2017). Municipal Bond Liquidity and Default Risk. Journal of Finance, 72(4), 1683-1722. https://doi.org/10.1111/jofi.12511

Wang, W., \& Hou, Y. (2012). Do Local Governments Save and Spend across Budget Cycles? Evidence from North Carolina. The America Review of Public Administration, 42(2), 152-169. https://doi.org/10.1177/0275074011398387

Wang, X., Dennis, L., \& Tu, Y. S. (2007). Measuring Financial Condition: A Study of U.S. States. Public Budgeting and Finance, 27(2), 1-21. https://doi.org/10.1111/j.1540-5850.2007.00872.x

\section{Copyrights}

Copyright for this article is retained by the author(s), with first publication rights granted to the journal.

This is an open-access article distributed under the terms and conditions of the Creative Commons Attribution license (http://creativecommons.org/licenses/by/4.0/). 